\title{
A study of Tribulus terrestris extract on risk factors for urinary stone in normal subjects and urolithic patients
}

\author{
Vasanthy Arasaratnam $^{1 *}$, S. Balakumar ${ }^{1}$, A. Senthuran ${ }^{1}$ and R. Rajendraprasad ${ }^{2}$ \\ ${ }^{1}$ Department of Biochemistry, Faculty of Medicine, University of Jaffna, Kokuvil. \\ 2 Department of Anatomy, Faculty of Medicine, University of Jaffna, Kokuvil.
}

\begin{abstract}
This study was conducted to determine the effect of Tribulus terrestis extract on urinary risk factors in normal subjects and urolithic patients. Twenty five urolithic patients and 18 normal subjects were selected and administered once daily with $10 \mathrm{~mL}$ of $T$. terrestris extract for one week. Serum, urine collected between $10 \mathrm{pm}$ and $6 \mathrm{am}$, and $24 \mathrm{~h}$ urine samples were analysed for urinary risk factors for stone formation on day 0 and day 8 after administration of the extract. In urolithic patients the mean serum calcium level increased significantly and the mean urinary calcium level decreased significantly after treatment for one week with $T$. terrestris extract. The mean uric acid level of the urolithic patients decreased significantly in serum and urine after treatment with $T$. terrestris extract. The mean citrate, oxalate, proteins and glycosaminoglycan levels decreased significantly in urine collected between $10 \mathrm{pm}$ and $6 \mathrm{am}$, and $24 \mathrm{~h}$ urine samples of the urolithic patients after treatment with the extract. Urine volume and phosphate level in serum were not altered significantly in the urolithic patients. Hence $T$. terrestris extract may be useful in the treatment of urolithiasis.
\end{abstract}

Keywords: Calcium, citrate, glycosaminoglycans, inorganic phosphate, oxalate, Tribulus terrestris extract, uric acid.

\section{INTRODUCTION}

Urolithiasis or urinary stone formation is a common health problem in the northern region of Sri Lanka. All forms of calculi are found in the kidney and urinary tract of patients. Urolithiasis is more prevalent in males than in females with the ratio of $4: 1^{1}$. Renal calculi are found mainly in adults while children tend to get vesicle calculi in situations where they are malnourished and also suffer from diarrhoea ${ }^{1}$. There are multiple factors involved in the stone formation. High intake of oxalate, carbohydrate, fat, purine, dairy products, proteins and sodium chloride increases the incidence of stone formation ${ }^{1}$. Individuals who work in warm environments and experience strenuous physical exertion are more prone to urolithiasis ${ }^{1,2}$. Further, Staphylococci and Proteus vulgaris infection facilitates the precipitation of crystals by splitting urea ${ }^{1}$. Most of the stones are developed by the deposition of glycosaminoglycans on an organic matrix ${ }^{3}$.

Allopurinol ${ }^{4,5}$, thiazide and several non-thiazide diuretics $^{6}$ and percutareous nephrostomy and hemiacidrin ${ }^{7}$ are used to treat urolithiasis. High energy shock waves were used to disintegrate kidney stones $^{8}$. Laser and pneumatic lithotripsy are safe and effective means of treatment ${ }^{9}$. Extra corporeal shock wave lithotripsy (ESWL) is a safer, more effective means in many cases. Some native extracts such as banana stem extract has also been tested in rats ${ }^{10,11}$. Rice bran therapy has been tested to prevent the recurrence of urinary stone disease ${ }^{12,13}$.

This paper describes a preliminary study carried out to reveal the effect of Tribulus terrestris extract in the urolithic patients. T. terrestris is a tropical plant distributed throughout India and Sri Lanka. The entire plant and particularly, the fruits are extensively used in indigenous medicine. The roots and fruits are useful in improving appetite, urinary output, vesicular calculi and pruritus ani, alleviate burning sensation, reduce inflammation, cough, asthma, and cure renal diseases ${ }^{14}$. T. terristris is useful in the treatment of urolithiasis, dysurea, impotence or erectile dysfunction and kidney dysfunction, and has also shown antibacterial \& antifungal activity and antiinflammatory activity ${ }^{15}$. The principal aim of this study is to assess the variations in the levels of uric acid, calcium, 
magnesium, citrate, oxalate, protein, glycosaminoglycans and urine volume before and after the administration of T. terrestris extract on the urolithic patients and the normal subjects.

\section{METHODS AND MATERIALS}

Selection of subjects: Twenty five renal stone patients and 18 normal individuals (volunteers) were selected. Their age ranged between 22-60 years. The patients were selected from the surgical ward, Teaching Hospital, Jaffna, who had been discharged without having any medication. Patients with urinary infection were excluded from the study. The patients selected were non-pregnant, without severe renal dysfunction and without signs of primary hyperparathyroidism. The approval of the Ethical Clearance Committee of the Faculty of Medicine, University of Jaffna was obtained for this study.

Preparation of T. terrestris extract: T. terrestris (Sinhala'Hokaddu'; Tamil-'Nerunchi'; family-Zygophyllaceae) extract was prepared as follows. The leaves, flowers and fruits $(10 \mathrm{~g})$ of $T$. terrestris plant were washed in distilled water, mixed with $450 \mathrm{~mL}$ of double distilled water and boiled until the volume was reduced to about $225 \mathrm{~mL}$.

Table 1: Composition of $T$. terrestris extract

\begin{tabular}{ll}
\hline Constituents & $\begin{array}{c}\text { Amount } \\
(\mathrm{g} / \mathrm{g} \text { T. terrestris })\end{array}$ \\
\hline urate & $5.5 \times 10^{-5}$ \\
calcium & $3.452 \times 10^{-3}$ \\
magnesium & $2.0 \times 10^{-5}$ \\
inorganic phosphate & $9.0 \times 10^{-5}$ \\
citrate & $1.08 \times 10^{-2}$ \\
oxalate & $1.38 \times 10^{-2}$ \\
glycosaminoglycans & $4.09 \mathrm{~mol}$ \\
\hline
\end{tabular}

Administration of the extract and collection of samples: T. terrestris extract $(10 \mathrm{~mL})$ was orally administered daily (Table 1) in the morning for $7 \mathrm{~d}$ to the patients and normal subjects who fasted overnight. Serum and urine were collected between $10 \mathrm{pm}$ and $6 \mathrm{am}$. Twenty four hour urine samples were collected from patients and normal individuals before and after the administration of $T$. terrestris extract, i.e. on day 0 and day 8. Urine samples were collected in a container with $10 \mathrm{~mL}$ of conc. $\mathrm{HCl}$ between $10 \mathrm{pm}$ and $6 \mathrm{am}$. The urine collection was continued for $24 \mathrm{~h}$ until the following day.

Analytical methods: T. terrestris extract was analysed for uric acid ${ }^{16}$, calcium $^{17}$, magnesium ${ }^{18}$, inorganic phosphate ${ }^{19}$, citric acid $^{20}$, oxalate ${ }^{21}$ and glycosaminoglycan ${ }^{22}$. Serum was analysed for uric acid $^{16}$, calcium ${ }^{17}$, magnesium ${ }^{18}$, and inorganic phosphate ${ }^{19}$. Urine collected between $10 \mathrm{pm}$ and $6 \mathrm{am}$, and $24 \mathrm{~h}$ urine samples were analysed for uric acid $^{16}$, calcium ${ }^{17}$, citric acid ${ }^{20}$, oxalate ${ }^{21}$ and inorganic phosphate ${ }^{19}$. Twenty four hour urine samples were also analysed for glycosaminoglycan ${ }^{22}$ and proteins ${ }^{23}$, and the urine volume was determined. Similar estimations were made with urine samples collected between $10 \mathrm{pm}$ and $6 \mathrm{am}$.

The mean and the standard deviations were calculated and the results were analysed with Students ' $t$ ' test.

\section{RESULTS}

After the administration of $10 \mathrm{~mL}$ of $T$. terrestris extract for a week, serum uric acid level in normal individuals and patients decreased significantly $(\mathrm{p}<0.05)$ (Table 2$)$. Uric acid levels in urine samples collected between $10 \mathrm{pm}$ and $6 \mathrm{am}$, and $24 \mathrm{~h}$ also decreased significantly in the normal subjects and the urolithic patients after the treatment $(\mathrm{p}<0.05)$ (Tables 3 and 4$)$.

Table 2: Changes in the serum calcium, uric acid, magnesium and inorganic phosphate of urolithic patients (25 nos.) and normal subjects (18 Nos.) before and after the administration of $T$. terrestris extract for one week

\begin{tabular}{|c|c|c|c|c|c|c|}
\hline \multirow[t]{2}{*}{ Parameters } & \multicolumn{3}{|c|}{ Patients } & \multicolumn{3}{|c|}{ Normal subjects } \\
\hline & Before & After & $\begin{array}{c}\text { Statistical } \\
\text { analysis }\end{array}$ & Before & After & $\begin{array}{c}\text { Statistical } \\
\text { analysis }\end{array}$ \\
\hline uric acid $\left(\mathrm{mg} \mathrm{L}^{-1}\right)$ & $77.30( \pm 16.1)$ & $38.50( \pm 8.1)$ & $\mathrm{p}<0.05$ & $47.0 \quad( \pm 19.4)$ & $39.8 \quad( \pm 19.9)$ & $\mathrm{p}<0.05$ \\
\hline calcium $(\mathrm{mmol} / \mathrm{L})$ & $2.47\left(\begin{array}{ll} \pm & 0.42\end{array}\right)$ & $2.68( \pm 0.29)$ & $\mathrm{p}<0.05$ & $2.38( \pm 0.008)$ & $2.50( \pm 0.021)$ & $\mathrm{p}<0.05$ \\
\hline magnesium $(\mathrm{mmol} / \mathrm{L})$ & $0.64( \pm 0.16)$ & $0.87( \pm 0.24)$ & $\mathrm{p}<0.05$ & $1.16( \pm 0.25)$ & $1.22( \pm 0.46)$ & $\mathrm{p}<0.05$ \\
\hline inorganic phosphate $(\mathrm{mmol} / \mathrm{L})$ & $0.58( \pm 0.03)$ & $0.70( \pm 0.12)$ & $\mathrm{p}<0.05$ & $2.009( \pm 1.063)$ & $2.041( \pm 0.98)$ & $\mathrm{p}<0.05$ \\
\hline calcium/ inorganic phosphate ratio & 4.26 & 3.83 & & 1.18 & 1.22 & \\
\hline
\end{tabular}

Values are indicated as the mean $( \pm \mathrm{SD})$ 
Table 3: Changes in the urinary calcium, uric acid, citric acid, oxalate and inorganic phosphate of urolithic patients (25 nos.) and normal subjects (18 nos.) before and after the administration of T. terrestris extract for one week

\begin{tabular}{|c|c|c|c|c|c|c|c|c|}
\hline \multirow[t]{2}{*}{ Parameters } & \multicolumn{5}{|c|}{ Patients } & \multicolumn{3}{|c|}{ Normal subjects } \\
\hline & Befo & fore & Aft & & $\begin{array}{c}\text { Statistical } \\
\text { analysis }\end{array}$ & Before & After & $\begin{array}{r}\text { Statistica } \\
\text { analysis }\end{array}$ \\
\hline uric acid $\left(\mathrm{mg} \mathrm{L}^{-1}\right)$ & 421.2 & $\pm 125.0)$ & 212.0 & $80.4)$ & $\mathrm{p}<0.05$ & $389.3 \quad( \pm 214.2)$ & $334.6( \pm 65.3)$ & $\mathrm{p}<0.05$ \\
\hline calcium $(\mathrm{mmol} / \mathrm{L})$ & $4.10( \pm$ & $\pm \quad 1.30)$ & $3.53( \pm$ & 1.49) & $\mathrm{p}<0.05$ & $2.82( \pm \quad 1.67)$ & $2.34( \pm \quad 0.65)$ & $\mathrm{p}<0.05$ \\
\hline citric acid $(\mathrm{mg} / \mathrm{L})$ & 550.0 & $\pm 350.0)$ & 570.0 & $460.0)$ & $\mathrm{p}>0.05$ & $740.0 \quad( \pm 360.0)$ & $750.0 \quad( \pm 560.0)$ & $\mathrm{p}>0.05$ \\
\hline oxalate $(\mathrm{mg} / \mathrm{L})$ & 24.16 & $\pm \quad 7.13)$ & $31.06( \pm$ & $8.03)$ & $\mathrm{p}<0.05$ & $25.02( \pm \quad 9.39)$ & ND & \\
\hline $\begin{array}{l}\text { inorganic phosphate }(\mathrm{mmol} / \mathrm{L})^{\prime} \\
\text { calcium/ inorganic phosphate ratio }\end{array}$ & $\begin{array}{l}6.10( \pm \\
0.672\end{array}$ & $\pm \quad 2.01)$ & $\begin{array}{l}8.06( \pm \\
0.437\end{array}$ & 2.96) & $\mathrm{p}<0.05$ & $\begin{array}{l}9.09\left(\begin{array}{ll} \pm & 0.3\end{array}\right) \\
0.310\end{array}$ & $\begin{array}{l}9.80( \pm \quad 0.45) \\
0.238\end{array}$ & $\mathrm{p}<0.05$ \\
\hline
\end{tabular}

ND- Not determined; values are indicated as the mean $( \pm \mathrm{SD})$

Table 4: Changes in the $24 \mathrm{~h}$ urinary calcium, uric acid, citric acid, oxalate, inorganic phosphate, glycosaminoglycan, protein and urine volume of urolithic patients ( 25 nos.) and normal subjects (18 nos.) before and after the administration of T. terrestris extract for one week

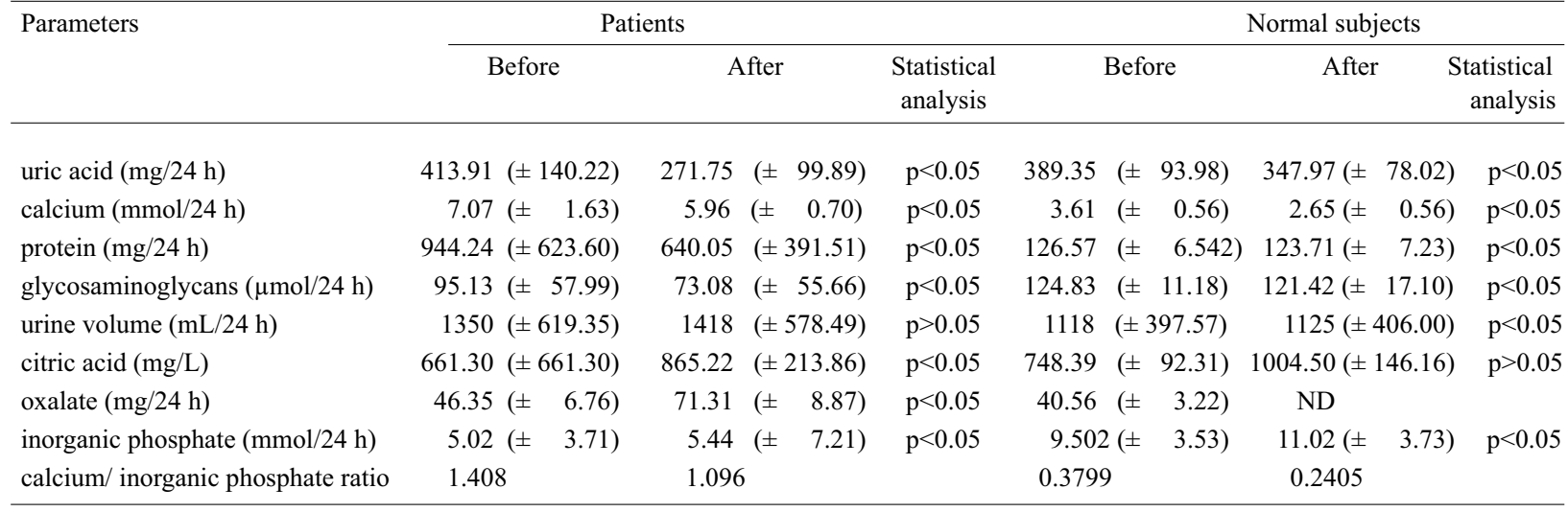

$\mathrm{ND}$ - Not Determined; Values are indicated as the mean $( \pm \mathrm{SD})$.

Twenty four hour urinary output in both the urolithic patients and normal individuals increased after treatment with the extract (Table 4).

After treatment with T. terrestris extract, the serum $\mathrm{Ca}^{2+}$ levels in the normal individuals and the patients increased significantly while the excretion of $\mathrm{Ca}^{2+}$ in the urine samples collected between $10 \mathrm{pm}$ and $6 \mathrm{am}$, and $24 \mathrm{~h}$ significantly decreased $(\mathrm{p}<0.05)$ (Tables 2,3 and 4$)$.

The mean $24 \mathrm{~h}$ urine total proteins and glycosaminoglycan levels reduced significantly in the urolithic patients and the normal subjects after the treatment with $T$. terrestris extract $(\mathrm{p}<0.05)$ (Table 4$)$.

The serum $\mathrm{Mg}^{2+}$ levels in the patients and the normal subjects increased significantly after the administration of T. terrestris extract $(\mathrm{p}<0.05)$ (Table 2).

In the patients, the levels of citrate excretion in the $10 \mathrm{pm}$ and 6 am samples became elevated but the increase was not statistically significant. However, citrate excretion in $24 \mathrm{~h}$ urine samples of the patients increased significantly, while that of the normal subjects also increased although not statistically significant. Oxalate excretion in urine collected between $10 \mathrm{pm}$ and $6 \mathrm{am}$, and after $24 \mathrm{~h}$ increased significantly $(\mathrm{p}<0.05)$ (Table 3$)$ in the patients after the treatment with $T$. terrestris extract.

The inorganic phosphate level in the serum of the patients and the normal individuals increased significantly after the administration of the extract (Table 2). The excretion of inorganic phosphate in the urine sample collected between $10 \mathrm{pm}$ and $6 \mathrm{am}$, and after $24 \mathrm{~h}$ also increased significantly in both the patients and normal individuals (Tables 3 and 4).

\section{DISCUSSION}

The significant decrease of serum uric acid level in the patients who received treatment could be explained by 
allopurinol-like action of T. terrestris extract. Allopurinol is a drug used in the treatment of hyperuricemia ${ }^{24}$. Allopurinol inhibits xanthine oxidase leading to a decrease in the formation of uric acid. Urate stones are formed in $15-20 \%$ of patients with hyperuricosuria ${ }^{4,5,25,26}$. The reduction in urinary uric acid level could be due to the consequence of the decrease in serum uric acid level. The increase in urinary uric acid level is a cause for urinary stone formation ${ }^{1}$ and therefore the $T$. terrestris extract has a positive effect on the reduction of urinary stone formation. While reducing the uric acid level in urine, the extract also increased the urine volume. This diuretic effect of the extract would help in the dilution of uric acid and thereby reducing urate stone formation. Stone formers must maintain a high urine volume ${ }^{6,27}$ to keep solutes well diluted ${ }^{1}$.

In both, the patients and normal individuals, the extract increased the serum calcium level and decreased urinary calcium excretion. Increased urinary calcium excretion is a high risk factor in renal stone formation ${ }^{28,29}$. The action of T. terrestris extract could be related to thiazide. Thiazide prevents recurrent calcium urolithiasis by reducing the urinary output of calcium ${ }^{29}$. Glycosaminoglycans are the major constituents of $T$. terrestris extract ${ }^{4}$, which are macromolecules and may reduce $\mathrm{Ca}^{2+}$ excretion by complexing with $\mathrm{Ca}^{2+}$. There is evidence that $T$. terrestris extract alters the tubular maximum for $\mathrm{Ca}^{2+}$ and increases its reabsorption in tubules ${ }^{27}$. Recent studies suggest that chondroitin sulphate and hyaluronic acid promote both growth rate and suspension density of the crystals ${ }^{3,25,31}$. T. terrestris could be altering the permeability of membranes and reducing the urinary excretion of glycosaminoglycans. Reduction in glycosaminoglycan urinary excretion (Table 4) might be due to the alteration in the membrane permeability of the Bowman's capsule and the stimulation of glycosyltransferase leading to formation of large molecules of glycosaminoglycans or due to the increased degradation of glycosaminoglycans. T. terrestris extract may reduce the degradation process and there may be larger glycosaminoglycans which cannot be filtered through the glomerular membrane. This may also reduce the urinary glycosaminoglycan concentration in urine after the $T$. terrestris extract administration ${ }^{1}$. Glycosaminoglycans of human urine have an influence on crystal aggregation. The diuretic effect of $T$. terrestris has been reported in Guinea pigs ${ }^{30}$.

T. terrestris extract contains high concentration of $\mathrm{Mg}^{2+}$ (Table 1) and also increases serum $\mathrm{Mg}^{2+}$ (Table 2). Magnesium inhibits calcium oxalate and calcium phosphate stone formation by inhibiting the formation and aggregation of calcium with oxalate and phosphate to form crystals in the urinary $\operatorname{tract}^{31}$.
Binding of magnesium with oxalate in the gut reduces its absorption and in urine prevents insoluble calcium oxalate formation. Reduction in urinary citrate output has been demonstrated in calcium oxalate stone secondary malabsorption syndromes ${ }^{2}$. Urinary citrate has an inhibitory effect on the lithogenesis of calcium salts at crystallisation stages. They inhibit the precipitation of calcium oxalate and calcium phosphate and prevent the growth and aggregation of both crystal types ${ }^{2}$. Thus, intake of $T$. terrestris extract could increase the citrate excretion and give a positive effect on the reduction of calcium stone formation.

In urine collected between $10 \mathrm{pm}$ and 6 am, the citrate excretion in both the patients and subjects was elevated, but the elevation was statistically not significant. However the excretion of citrate in $24 \mathrm{~h}$ urine was significant both in the patients and normal subjects. This elevated level could also be due to the direct contribution by the extract. Citrate chelates calcium and hence considered to be an inhibitor of urinary stone formation ${ }^{2}$.

There was an increase in the serum calcium level with an increase in inorganic phosphate level (Table 2). The effects on the patients and the normal subjects were different because the serum calcium to phosphate ratio was lowered in the patients while it was increased in the normal subjects. The urine samples collected between $10 \mathrm{pm}$ and $6 \mathrm{am}$, and $24 \mathrm{~h}$ from the patients and the normal subjects contained reduced calcium to inorganic phosphate ratio (Tables 3 and 4). Neutral phosphates decrease renal calcium excretion and increase renal pyrophosphate excretion. Inorganic phosphate therapy increases the serum phosphorous concentration and in turn it decreases the serum calcium concentration ${ }^{6}$.

\section{CONCLUSION}

This preliminary study shows that administration of T. terrestris extract brings about changes in the levels of the risk factors, which cause or activate the urinary stone formation. After the administration of T.terrestris extract, the levels of uric acid, oxalate, calcium, proteins and glycosaminoglycans in serum and urine changed significantly, while the citrate, inorganic phosphate and urine volume were not significantly affected. Therefore the $T$. terrestris extract may be useful in the treatment of urolithiasis.

\section{Acknowledgement}

The authors thank Mrs. K. Sritharan, Mrs. K. Nithiyanantharajah, Mr. N. Nithiyanantharajah and Mr. K. Thayananthan of the Department of Biochemistry, 
Faculty of Medicine, University of Jaffna for technical support and Mr. T. Santhiramoorthy for clerical assistance.

\section{References}

1. Smith D.R. (1975). Urinary stones. In: General Urology (Eds. E.A. Tanagho \& J.W. McAninch). $8^{\text {th }}$ edition, pp. 200-216. Lange Medical Publications, Los Altas, California.

2. Fellstrom B., Danielson B.G., Karlstrom B., Lithell H., Ljunghall S., Vessby B. \& Wide L. (1984). Effects of high intake of dietary animal protein on mineral metabolism and urinary super saturation of calcium oxalate in renal stone formers. British Journal of Urology 56(3): 263-269.

3. Ryall R.L., Harnett R.M. \& Marshall V.R. (1986). The effect of monosodium urate on the capacity of urine, chondroitin sulphate and heparin to inhibit calcium oxalate crystal growth and aggregation. The Journal of Urology 135(1): 174-177.

4. Cameron J.S. \& Simmonds H.A. (1987). Use and abuse of allopurinol. British Medical Journal 294: 1504-1505.

5. Coe F.L. \& Raisin L. (1973). Allopurinol treatment of uric acid disorders in calcium stone formers. The Lancet I (7795): 129-131.

6. Abraham P.A. \& Smith C.L. (1984). Medical evaluation and management of calcium nephrolithiasis. Medical Clinics of North America 68(2): 281-299.

7. Dretler S.P. \& Pfister R.C. (1984). Primary dissolution therapy of struvite calculi. Journal of Urology 131(5): 861-863.

8. Chaussy C., Brendel W. \& Schmiedt E. (1980). Extrcoporeally induced destruction of kidney stones by shock waves. The Lancet II(8207): 1265-1268.

9. Naqvi S.A.A., Khaliq M., Zafar M.N. \& Rizvi S.A.H. (1994). Treatment of ureteric stones. Comparison of laser and pneumatic lithotripsy. British Journal of Urology 74: 694-698.

10. Poonguzhali P.K. \& Chegu H. (1994). The influences of banana stem extract on urinary risk factors for stones in normal and hyperoxaluric rats. British Journal of Urology 74(1): 23-25.

11. Prasad K.V.S.R.G., Sujatha D. \& Bharathi K. (2007). Herbal drugs in urolithiasis- a review. Pharmacognosy Reviews 1(1): 175-179.

12. Ebisuno S., Morimoto S., Yoshida T., Fukatani T., Yasukawa S. \& Ohkawa T. (1986). Rice bran treatment for calcium stone formers with idiopathic hypercalciuria. British Journal of Urology 58(6): 592-595.

13. Ohkawa T. \& Morimoto S. (1987). Methods for preventing the recurrence of urinary stone disease. Asian Medical Journal 30(3): 143 - 148.

14. Kirtikar K.R. \& Basu B.D. (1993). Tribulus terrestris. In: Indian Medicinal Plants. Vol. 1, $2^{\text {nd }}$ edition. pp. 420-424. Periodical Expert Book Agency, Delhi.

15. Al-Bayati F.A. \& Al-Mola H.F. (2008). Antibacterial and antifungal activity of different parts of Tribulus terristris
L. growing in Iraq. Journal of Zhejiang University Science B 9(2):154-159.

16. Varley H., Gowenlock A.H. \& Bell M. (1980). Practical Clinical Biochemistry. $5^{\text {th }}$ edition. pp 465-478. William Heinemann Medical Books Ltd, London.

17. Billimoria J.D. \& James D.C.O. (1960). Two improved methods for serum cholesterol estimation. Clinica Chemica Acta 5(5):644-651.

18. Friedman H.S. \& Rubin M.A. (1955). Determination of Magnesium by titration method. Clinical Chemistry 1: 125.

19. Fiske C.H. \& Subbarow Y. (1925). Determination of inorganic phosphate. Journal of Biological Chemistry 66: 375.

20. Marier J.R. \& Boulet M. (1958). Direct determination of citric acid in milk with improved pyridine- acetic anhydride method. Journal of Dairy Science 41: 1683-1688.

21. Vogel A.I. (1948). A Text book of Quantitative Inorganic Analysis. Theory and Practice. pp 340-341. Longmans Green and Co., London.

22. Fischer R.W., De Jona C., Voigt E., Berger W. \& Winterhalter K.H. (1980). The colorimetric determination of $\mathrm{HbA}_{1 \mathrm{C}}$ in normal and diabetic subjects. Clinical Lab Haematology 2(2): $126-138$.

23. Lowry O.H., Rosenbrough M.H., Farr A.L. \& Randall R.J. (1951). Protein measurement with Folin - Phenol reagent. Journal of Biological Chemistry 193: 265-275.

24. Finlayson B., Newman R.C. \& Hunter P. T. (1984). The role of urate and allopurinol in stone diseases: a review. In: Urolithiasis and Related Clinical Research (Eds. P.O. Schwille, L.H. Smith, W.G. Robertson \& K.W. Vahlensieck) pp 499 - 502. Pleanum Press, New York.

25. Fellstrom B., Backman U., Danielson B. G., Holmgren K., Johansson G., Lindsjo M., Ljunghall S. \& Wikstrom B. (1985). Allopurinol treatment of renal calcium stone disease. British Journal of Urology 57: 375-379.

26. Coe F.L. (1981). Prevention of kidney stones. The American Journal of Medicine 71: 514-516.

27. Harper J.M., Samuell C.T., Hallson P.C., Wood S.M. \& Mansell M.A. (1994). Risk factors for calculus formation in patients with renal transplant. British Journal of Urology 74: $147-150$.

28. Anderson C.K., Hodgkinson A. \& Pyrah L.N. (1961). Renal calcification calculus formation and the urinary excretion of calcium. The Lancet II(7200): 454-455.

29. Ohkawa M., Tokunaga S., Nakashima T., Orito M. \& Hisazumi H. (1992). Thiazide treatment for calcium urolithiasis in patients with idiopathic hyperurcalciuria. British Journal of Urology 69:571-576.

30. Al-Ali M., Wahbi S., Twaij H \& Al-Badr A. (2003). Tribulus terrestris: preliminary study of its diuretic and contractile effets and comparison with Zea mays. Journal of Ethnopharmacology 85(2-3): 257-260.

31. Grases F., Genestar C., Conte A., March P. \& Cost-Bauza A. (1989). Inhibitory effect of pyrophosphate, Urate, Magnesium and Chondroitin sulphate in Calcium Oxalate urolithiasis. British Journal of Urology 64: 235-237. 